\title{
Follow-up of ventilatory lung function in a group of cement workers
}

\author{
MARKO ŠARIĆ, IVO KALAČIC, and ANKICA HOLETIC \\ Institute for Medical Research and Occupational Health, Yugoslav Academy of Sciences and \\ Arts, Moše Pijade 158, 41000 Zagreb, Yugoslavia
}

\begin{abstract}
Šarić, M., Kalačić, I., and Holetić, A. (1976). British Journal of Industrial Medicine, 33, 18-24. Follow-up of ventilatory lung function in a group of cement workers. In a group of 160 active cement workers and 80 control workers selected on the basis of having or not having symptoms of chronic bronchitis, forced vital capacity (FVC) and one second expiratory volume (FEV 1.0 ), both corrected for age and height, and ratio of one second forced expiratory volume to forced vital capacity $\left(\mathrm{FEV}_{1.0} / \mathrm{FVC}(\%)\right)$ were measured on two occasions with an interval of four and eight years respectively. The mean initial values of the forced expiratory indices and mean changes of these indices were computed in the total sample and in the following pairs of contrasted subgroups: chronic bronchitics-healthy workers: nonsmokers-smokers; youngerolder; exposed up to 10 years-exposed 10 or more years in cement plants; re-examined after four years-re-examined after eight years. In the group of cement workers as well as in the group of controls the values of ventilatory indices declined significantly during the follow-up period. Comparing the groups as a whole, using paired $t$ test, only $\mathrm{FEV}_{1 \cdot 0} / \mathrm{FVC}(\%)$ values differed between cement and control workers with a statistically significant reduction in cement workers but not in controls. The analysis took into account the effects of smoking, symptoms of chronic bronchitis, age, duration of previous exposure to cement dust, and the interval between the two examinations. The rate of deterioration in ventilatory indices was fastest in the older workers with longest exposure. The decline in FVC does not seem to be affected by these factors. The results suggest that occupational exposure may contribute to the development of expiratory airflow obstruction.
\end{abstract}

In a previous cross-sectional study of ventilatory lung function in cement workers (Kalačić, 1973) an inverse relationship between duration of occupational exposure and values of forced vital capacity (FVC) and ratio of one second forced expiratory volume to forced vital capacity $\left(\mathrm{FEV}_{1.0} / \mathrm{FVC}(\%)\right)$ was found. The purpose of the present follow-up study was to examine the possible effect of smoking, chronic bronchitis, age, and duration of previous exposure in cement plant on the rate of change in ventilatory indices during a period of several years of exposure.

\section{Sample and method}

From a group of cement workers who were examined in
1964 and from another group of cement workers who were examined in 1968, 219 were invited for the second examination in 1972. Those who were invited for the reexamination were selected from the original population as follows:

(a) 'Chronic bronchitics'. These were all the workers who complained when first seen of increased phlegm in the morning and during the day or night for three winter months for at least two years.

(b) Healthy workers. These were the workers who did not have any of the following when first seen:

(i) Chronic bronchitis as defined above.

(ii) Wheezing in the chest not necessarily associated with colds.

(iii) Dyspnoea grade 3 or worse.

(iv) One second forced expiratory volume $75 \%$ or lower of the predicted value. 
The over-all response rate was $86 \%$. Out of 188 examined workers 28 were found to be retired after the first examination; these were excluded from the study.

Shipbuilding workers who had served as controls for the original study were again used. Altogether 62 'healthy' and 18 'chronic bronchitic' shipbuilding workers were chosen using the same criteria as for the cement workers, and were re-examined in 1972 . The response rate for this group of workers was practically the same as for cement workers-84\%. (Altogether 22 chronic bronchitic controls and 73 healthy worker controls were invited for examination.)

The technique of testing ventilatory function was the same as in the first examination. Timed forced expiratory vital capacity was recorded at least three times on a waterless spirometer. While performing the expiratory manoeuvre the workers were in a standing position and a nose clip was used. From one of two identical or similar tracings FVC and FEV $_{1.0}$ were measured. The retardation of flow occasionally seen at the beginning of forced expiration as the consequence of a submaximal effort was corrected by an extrapolation of the steepest portion of the curve on the base line. The $\mathrm{FEV}_{1.0}$ was read from this intersection. The FVC and FEV 1.0 were expressed in percentages of predicted values. The nomograms used were the same as in the first examination (Jouasset, 1960). The $\mathrm{FEV}_{1.0}$ was expressed also as the percentage of FVC. The examination took place before, during, or after the work shift. The workers were not allowed to smoke for at least half an hour before spirometric testing. The mean initial values of $\mathrm{FVC}(\%)$, $\mathrm{FEV}_{1.0}(\%)$, and $\mathrm{FEV}_{1.0} / \mathrm{FVC}$ ratio, and mean changes of these indices during the period between the two examinations were computed in the total sample of cement workers and controls and in the following pairs of contrasted subgroups: 1(a) chronic bronchitics, 1(b) healthy workers, 2(a) nonsmokers, those who were registered as nonsmokers in the first and in the second examination, 2(b) smokers, those who were registered as ex-smokers or present smokers in the second examination, 3(a) workers below 40 years of age, 3(b) workers of 40 or more years of age, 4(a) workers exposed up to 10 years, and 4(b) workers exposed 10 or more years in cement plants, 5(a) workers re-examined after 4 years, 5(b) workers re-examined after 8 years. The classification of workers according to age and duration of exposure was based on data obtained in the first examination.

Table 1 shows the characteristics of cement and control workers.

The significance of the differences in ventilatory indices during the follow-up period was examined by paired $t$ test. Unpaired $t$ test was used to evaluate the significance of the differences in initial values of the forced expiratory volumes between the contrasted subgroups.

\section{Results}

The initial mean values of ventilatory indices and their mean change during the follow-up period in the total sample of cement and control workers and in contrasted subgroups of workers are presented in Tables 2 to 7. As seen in Table 2 the initial mean values in the total sample of cement workers as well as in controls were within normal limits.

There was a statistically significant decline in $\mathrm{FEV}_{1.0}$ and FVC in both cement workers and controls between the first and second examination. The $\mathrm{FEV}_{1 \cdot 0} / \mathrm{FVC}$ ratio fell significantly in the cement workers but not significantly in the controls.

When the cement and control group of workers are compared by being divided into subgroups with and without chronic bronchitis (Table 3) the interval between the first and repeated examination in both subgroups of cement workers shows a significant reduction in the values of all three ventilatory indices. In controls such decrement was not noticed in workers with symptoms of chronic bronchitis, but it was recorded in those who were considered healthy. The initial values of forced expiratory volumes did not differ between the contrasted subgroups of chronic bronchitics and healthy workers, while within the group of cement workers they differed only for $\mathrm{FEV}_{1 \cdot 0} / \mathrm{FVC}$ ratio. Within the

TABLE 1

Characteristics of Cement and Control Workers Groups

\begin{tabular}{|c|c|c|c|c|c|c|c|c|c|}
\hline \multicolumn{7}{|c|}{ Characteristics } & $\begin{array}{c}\begin{array}{c}\text { Cement } \\
\text { workers } \\
(N=160)\end{array} \\
58(36 \cdot 2)\end{array}$ & $\begin{array}{c}\begin{array}{c}\text { Control } \\
\text { workers } \\
(N=80)\end{array} \\
35(43 \cdot 7)\end{array}$ & $\begin{array}{c}\begin{array}{l}\text { Significance } \\
\text { of difference }\end{array} \\
\text { NS }\end{array}$ \\
\hline $\begin{array}{l}<40 \text { yrs of age } \\
\geq 40 \text { yrs of age } \\
\text { Chronic bronchitics } \\
\text { Healthy workers } \\
\text { Smokers } . \\
\text { Nonsmokers } \ldots \\
\text { Re-examined after } 4 \\
\text { Exposure }<10 \text { yrs } \\
\geq 10 \text { yrs }\end{array}$ & $\begin{array}{l}\cdots \\
\cdots \\
\cdots \\
\cdots \\
\cdots \\
4 \text { yrs } \\
8 \text { yrs } \\
\cdots \\
\cdots\end{array}$ & $\begin{array}{l}\ldots \\
\ldots \\
\ldots \\
\ldots \\
\ldots \\
\ldots \\
\ldots \\
\ldots \\
\ldots\end{array}$ & $\begin{array}{l}\cdots \\
\cdots \\
\cdots \\
\cdots \\
\cdots \\
\cdots \\
\cdots \\
\ldots\end{array}$ & $\begin{array}{l}\cdots \\
\cdots \\
\cdots \\
\cdots \\
\cdots \\
\cdots \\
\cdots \\
\cdots\end{array}$ & $\begin{array}{l}\cdots \\
\ldots \\
\ldots \\
\ldots \\
\ldots \\
\ldots \\
\ldots \\
\ldots \\
\ldots\end{array}$ & $\begin{array}{l}\cdots \\
\ldots \\
\ldots \\
\ldots \\
\ldots \\
\ldots \\
\ldots \\
\ldots \\
\ldots\end{array}$ & $\begin{array}{r}58(36 \cdot 2) \\
102(63 \cdot 8) \\
41(25 \cdot 6) \\
119(74 \cdot 4) \\
118(73 \cdot 7) \\
42(26 \cdot 3) \\
48(30 \cdot 0) \\
112(70 \cdot 0) \\
59(36 \cdot 9) \\
101(63 \cdot 1)\end{array}$ & $\begin{array}{l}35(43 \cdot 7) \\
45(56 \cdot 3) \\
18(22 \cdot 5) \\
62(77 \cdot 5) \\
57(71 \cdot 3) \\
23(28 \cdot 7) \\
11(13 \cdot 7) \\
69(86 \cdot 3) \\
-\end{array}$ & $\begin{array}{c}\text { NS } \\
\text { NS } \\
\text { NS } \\
\text { NS } \\
\text { NS } \\
\text { NS } \\
P<0.01 \\
P<0.01\end{array}$ \\
\hline
\end{tabular}

Percentages are given in parentheses 
TABLE 2

Mean Initial Values and Mean Changes of Ventilatory Volumes during the Follow-up Period in Total Sample of Cement and Control Workers

\begin{tabular}{|c|c|c|c|c|c|c|c|}
\hline \multirow{2}{*}{$\begin{array}{c}\text { Ventilatory } \\
\text { volume }\end{array}$} & & \multicolumn{3}{|c|}{ 1. Cement workers $(N=160)$} & \multicolumn{3}{|c|}{ 2. Control workers $(N=80)$} \\
\hline & & $\underset{\text { Mean }}{\text { Initial values }} S_{\bar{x}}$ & $\begin{array}{c}\text { Changes } \\
\text { Mean } \quad S_{\bar{x}}\end{array}$ & $\begin{array}{c}\text { Significance } \\
\text { of } \\
\text { difference }\end{array}$ & $\begin{array}{l}\text { Initial values } \\
\text { Mean } S_{\bar{x}}\end{array}$ & $\underset{\text { Mean }}{\text { Changes }} S_{\bar{x}}$ & $\begin{array}{c}\text { Significance } \\
\text { of } \\
\text { difference }\end{array}$ \\
\hline $\begin{array}{ll}\text { FVC }(\%) & . \\
\text { FEV }_{1.0}(\%) & \ldots \\
\text { FEV }_{1.0} / \text { FVC }(\%)\end{array}$ & $\begin{array}{l}\cdots \\
\cdots \\
\cdots\end{array}$ & $\begin{array}{l}96 \cdot 0 \\
93 \cdot 5 \\
75 \cdot 4\end{array}$ & $\begin{array}{ll}-2.8 & 0.7 \\
-3.1 & 1.0 \\
-1.9 & 0.7\end{array}$ & $\begin{array}{l}\mathbf{P}<0.01 \\
\mathbf{P}<0.01 \\
P<0.01\end{array}$ & $\begin{array}{l}93 \cdot 7 \\
93 \cdot 0 \\
77 \cdot 2\end{array}$ & $\begin{array}{ll}-3.9 & 0.8 \\
-2.4 & 1.1 \\
-1.0 & 0.8\end{array}$ & $\begin{array}{l}\mathbf{P}<0.01 \\
\mathbf{P}<0.01 \\
\mathbf{P}>0.10\end{array}$ \\
\hline
\end{tabular}

Significance of difference

of initial values $(1-2)$

$\begin{array}{ll}\text { FVC (\%) } & \text { NS } \\ \text { FEV }_{1.0}(\%) & \text { NS } \\ \text { FEV }_{1.0} / \text { FVC (\%) } & \text { NS }\end{array}$

TABLE 3

Mean Initial Values and Mean Changes of Ventilatory Volumes during the Follow-up Period in Chronic Bronchitics and in Healthy Subjects in Cement and Control Workers Groups

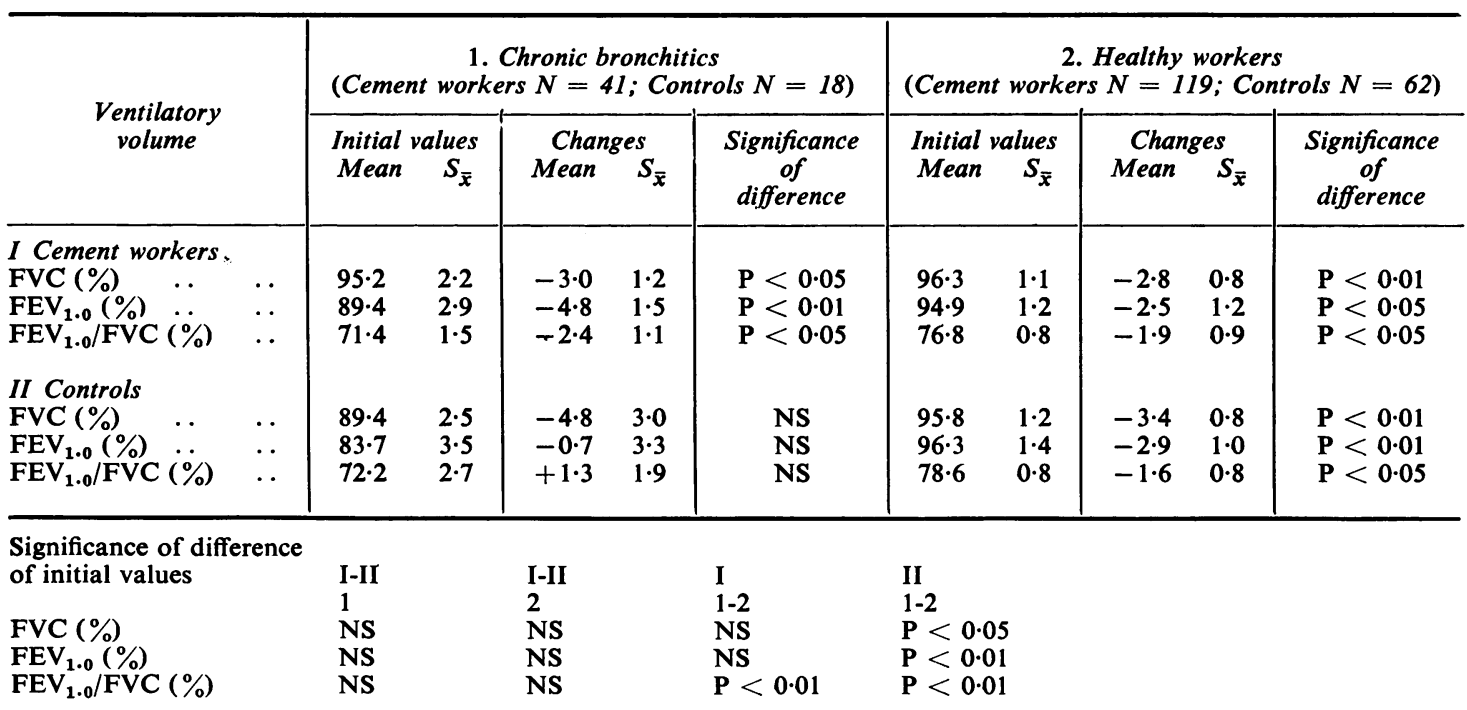

control group for all three indices the initial values were significantly higher in healthy workers than in those with the symptoms of chronic bronchitis.

A comparative analysis of results with regard to smoking habit (Table 4) showed that in cement workers who smoke there was a significant decrement in the values of all three expiratory indices while in nonsmokers the decline concerned only $\mathrm{FEV}_{1 \cdot 0} / \mathrm{FVC}(\%)$ values. In control workers only the FVC values declined significantly in both smokers and nonsmokers. A comparison of initial values of expiratory volumes between the group of cement and control workers as well as the comparison within these groups as regards smoking habit did not show a statistically significant difference.

If age is taken into consideration (Table 5) it appears that in cement workers of $\mathbf{4 0}$ or more years all ventilatory indices show a significant decrement between the first and repeated examination, while in those below 40 years this was observed for FVC only. In control workers reduced values were found only in the group of older workers for FVC and FEV 1.0. Significant differences in initial values of ventilatory volumes were not found in comparisons between subgroups.

With regard to the interval between examinations 
TABLE 4

Mean Initial Values and Mean Changes of Ventilatory Volumes during the Follow-up Period in SMOKERS AND IN NONSMOKERS IN CEMENT AND CONTROL WORKERS Groups

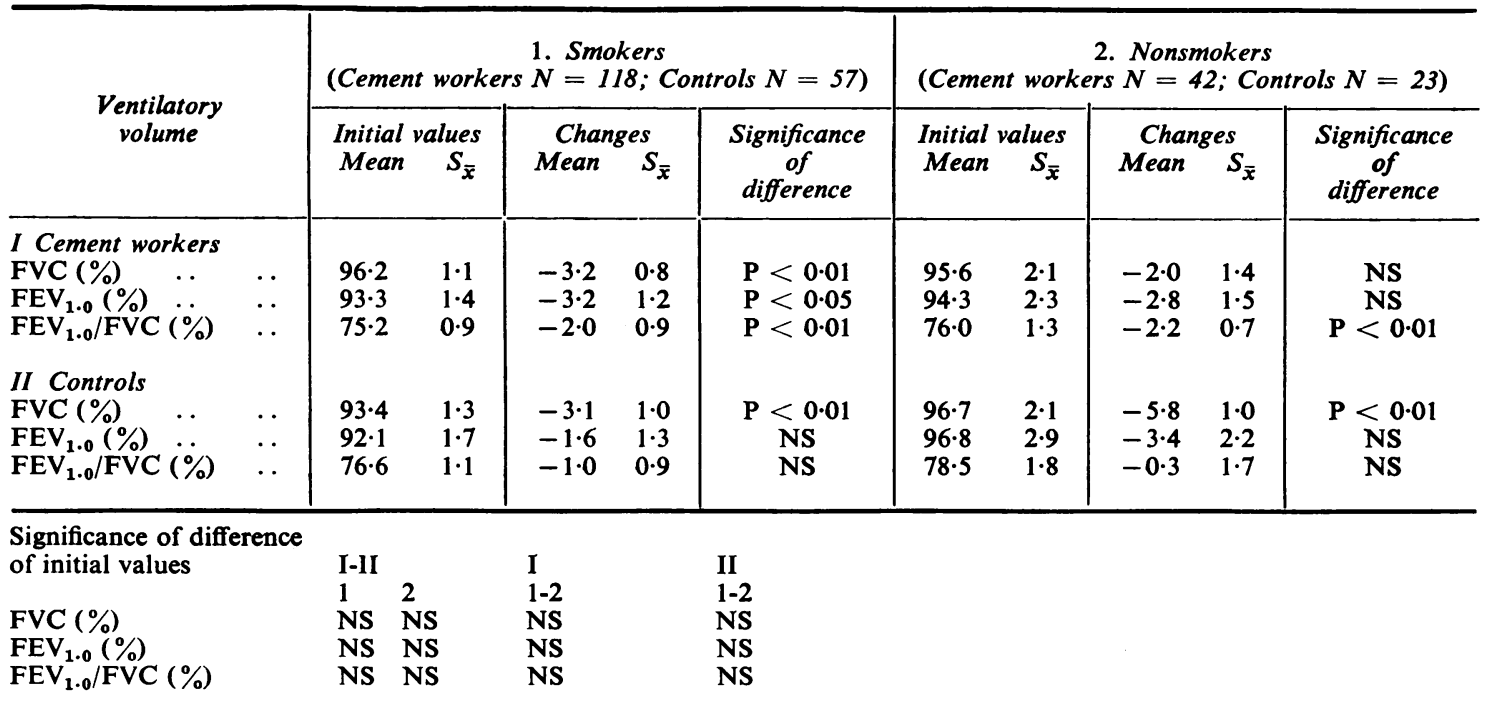

TABLE 5

Mean Initial Values and Mean Changes of Ventilatory Volumes during the Follow-up Period in Two Age Subgroups of Cement and Control Workers

\begin{tabular}{|c|c|c|c|c|c|c|c|c|c|c|c|}
\hline \multirow{2}{*}{$\begin{array}{c}\text { Ventilatory } \\
\text { volume }\end{array}$} & & \multicolumn{5}{|c|}{$\begin{array}{l}1 .<40 \text { yrs of age } \\
\text { (Cement workers } N=58 ; \text { Controls } N=35)\end{array}$} & \multicolumn{5}{|c|}{$\begin{array}{c}2 . \geq 40 \text { yrs of age } \\
\text { (Cement workers } N=102 \text {; Controls } N=45)\end{array}$} \\
\hline & & $\begin{array}{l}\text { Initial } \\
\text { Mean }\end{array}$ & $\begin{array}{l}\text { values } \\
\qquad S_{\bar{x}}\end{array}$ & $\begin{array}{c}\text { Chan } \\
\text { Mean }\end{array}$ & & $\begin{array}{c}\text { Significance } \\
\text { of } \\
\text { difference }\end{array}$ & $\begin{array}{c}\text { Initial } \\
\text { Mean }\end{array}$ & $\begin{array}{c}\text { alues } \\
S_{\bar{x}}\end{array}$ & $\begin{array}{c}\text { Char } \\
\text { Mean }\end{array}$ & $\stackrel{\text { ges }}{S_{\bar{x}}}$ & $\begin{array}{c}\text { Significance } \\
\text { of } \\
\text { difference }\end{array}$ \\
\hline $\begin{array}{l}\text { I Cement workers } \\
\text { FVC }(\%) \quad \cdots \\
\text { FEV }_{1.0}(\%) \quad 0 \\
\text { FEV }_{1.0} / \text { FVC }(\%)\end{array}$ & $\begin{array}{l}\cdots \\
\cdots \\
\cdots\end{array}$ & $\begin{array}{l}97 \cdot 9 \\
94 \cdot 7 \\
76 \cdot 5\end{array}$ & $\begin{array}{l}1 \cdot 4 \\
1.8 \\
1 \cdot 1\end{array}$ & $\begin{array}{l}-3 \cdot 1 \\
-1.5 \\
-0.7\end{array}$ & $\begin{array}{l}1 \cdot 0 \\
1 \cdot 5 \\
1 \cdot 1\end{array}$ & $\begin{array}{c}P<0 \cdot 01 \\
\text { NS } \\
\text { NS }\end{array}$ & $\begin{array}{l}95 \cdot 0 \\
92.9 \\
74.9\end{array}$ & $\begin{array}{l}1 \cdot 3 \\
1 \cdot 6 \\
1 \cdot 0\end{array}$ & $\begin{array}{l}-2 \cdot 8 \\
-4 \cdot 1 \\
-2 \cdot 9\end{array}$ & $\begin{array}{l}0.9 \\
1.3 \\
0.9\end{array}$ & $\begin{array}{l}\mathbf{P}<0.01 \\
\mathbf{P}<0.01 \\
\mathbf{P}<0.01\end{array}$ \\
\hline $\begin{array}{l}\text { II Controls } \\
\text { FVC }(\%) \\
\text { FEV }_{1.0}(\%) \quad \ldots \\
\text { FEV }_{1.0} / \text { FVC }(\%)\end{array}$ & $\begin{array}{l}. \\
\cdots \\
\cdots\end{array}$ & $\begin{array}{l}95 \cdot 0 \\
93 \cdot 2 \\
77 \cdot 9\end{array}$ & $\begin{array}{l}1 \cdot 5 \\
2 \cdot 3 \\
1 \cdot 5\end{array}$ & $\begin{array}{l}-1.5 \\
+1.6 \\
-0.1\end{array}$ & $\begin{array}{l}1 \cdot 1 \\
1 \cdot 8 \\
1 \cdot 3\end{array}$ & $\begin{array}{l}\text { NS } \\
\text { NS } \\
\text { NS }\end{array}$ & $\begin{array}{l}93 \cdot 8 \\
93 \cdot 6 \\
76 \cdot 6\end{array}$ & $\begin{array}{l}1 \cdot 5 \\
2 \cdot 0 \\
1 \cdot 1\end{array}$ & $\begin{array}{l}-5 \cdot 8 \\
-5 \cdot 4 \\
-1 \cdot 6\end{array}$ & $\begin{array}{l}1 \cdot 1 \\
1 \cdot 1 \\
0 \cdot 9\end{array}$ & $\begin{array}{l}\mathbf{P}<0.01 \\
\mathbf{P}<0.01 \\
. \quad \text { NS }\end{array}$ \\
\hline $\begin{array}{l}\mathrm{FVC}(\%) \\
\mathrm{FEV}_{1.0}(\%) \\
\mathrm{FEV}_{1.0} / \mathrm{FVC}(\%)\end{array}$ & & $\begin{array}{ll}\text { I-II } & \\
1 & 2 \\
\text { NS } & N \\
\text { NS } & N \\
\text { NS } & N\end{array}$ & $\begin{array}{l}2 \\
\text { NS } \\
\text { NS } \\
\text { NS }\end{array}$ & $\begin{array}{l}\text { I } \\
1-2 \\
\text { NS } \\
\text { NS } \\
\text { NS }\end{array}$ & & $\begin{array}{l}\text { II } \\
1-2 \\
\text { NS } \\
\text { NS } \\
\text { NS }\end{array}$ & & & & & \\
\hline
\end{tabular}

(Table 6) neither in the group of cement workers nor in the group of controls was a statistically significant decrease in the values of forced expiratory volumes observed when the interval was only four years. However, a statistically significant reduction was found both in cement and control workers for all volumes (with the exception of $\mathrm{FEV}_{1.0} / \mathrm{FVC}(\%)$ in controls) when the interval was eight years. The mean initial FVC was significantly lower in control workers than in cement workers in the group examined after four years. The initial $\mathrm{FEV}_{1.0}$ values were lower in the group of control workers examined after four 
TABLE 6

Mean Initial Values and Mean Changes of Ventilatory Volumes during the Follow-up Period BY THE TIME OF RE-EXAMINATION

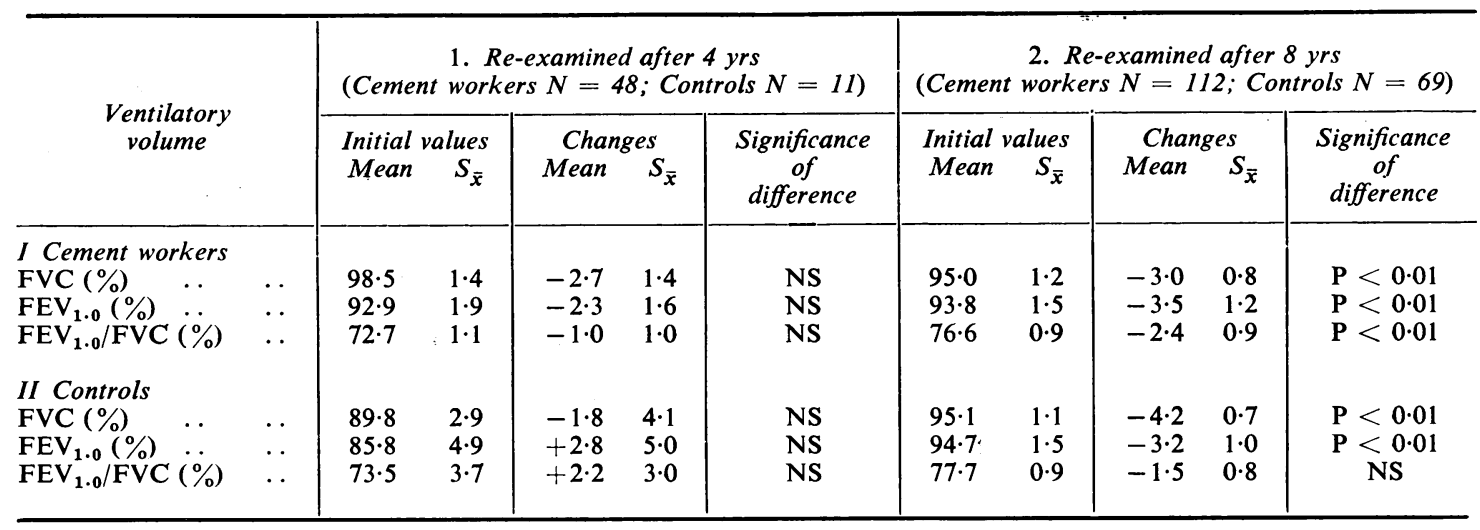

Significance of difference of initial values

\section{FVC (\%)}

FEV $_{1.0}(\%)$

FEV $_{1.0} /$ FVC (\%)

$\begin{array}{ll}\text { I I-II } & \\ \text { P }<0.05 & 2 \\ \text { NS } & \text { NS } \\ \text { NS } & \text { NS } \\ & \text { NS }\end{array}$

I
$1-2$
NS
NS
NS

II
$1-2$
NS
P $<0.05$
NS

TABLE 7

Mean Initial Values and Mean Changes of Ventilatory Volumes during the Follow-up Period by Duration of Previous Exposure in Cement Plant

\begin{tabular}{|c|c|c|c|c|c|c|c|}
\hline \multirow[b]{2}{*}{$\begin{array}{c}\text { Ventilatory } \\
\text { volume }\end{array}$} & & \multicolumn{3}{|c|}{ 1. Exposure $<10$ yrs $(N=59)$} & \multicolumn{3}{|c|}{ 2. Exposure $>10$ yrs $(N=101)$} \\
\hline & & $\begin{array}{c}\text { Initial values } \\
\text { Mean }\end{array} S_{\bar{x}}$ & $\begin{array}{c}\text { Changes } \\
\text { Mean } S_{\bar{x}}\end{array}$ & $\begin{array}{c}\text { Significance } \\
\text { of } \\
\text { difference }\end{array}$ & $\begin{array}{c}\text { Initial values } \\
\text { Mean } \quad S_{\bar{x}}\end{array}$ & $\begin{array}{c}\text { Changes } \\
\text { Mean } S_{\ddot{x}}\end{array}$ & $\begin{array}{c}\text { Significance } \\
\text { of } \\
\text { difference }\end{array}$ \\
\hline $\begin{array}{l}F V C(\%) \\
F E \\
F_{1.0}(\%) \quad \ldots \\
F_{1.0} / F V C(\%)\end{array}$ & $\begin{array}{l}\ldots \\
\cdots \\
\cdots\end{array}$ & $\begin{array}{l}99 \cdot 7 \\
95 \cdot 9 \\
75 \cdot 5\end{array}$ & $\begin{array}{ll}-3.7 & 1.3 \\
-2.4 & 1.6 \\
-1.1 & 1.2\end{array}$ & $\begin{array}{c}P<0.01 \\
\text { NS } \\
\text { NS }\end{array}$ & $\begin{array}{l}93 \cdot 9 \\
92 \cdot 1 \\
75 \cdot 3\end{array}$ & $\begin{array}{ll}-2.4 & 0.8 \\
-3.5 & 1.3 \\
-2.4 & 0.9\end{array}$ & $\begin{array}{l}\mathbf{P}<0.01 \\
\mathbf{P}<0.01 \\
\mathbf{P}<0.01\end{array}$ \\
\hline
\end{tabular}

Significance of difference of initial values (1-2)

$\begin{array}{ll}\text { FVC (\%) } & \text { P }<0.01 \\ \text { FEV (\%) } & \text { NS } \\ \text { FEV }_{1.0} / \text { FVC (\%) } & \text { NS }\end{array}$

years when compared with the group of control workers who were examined after eight years.

When the cement workers were divided into subgroups according to duration of exposure (Table 7) the values of all forced expiratory volumes showed a significant decrease if exposure exceeded 10 years. With shorter exposure, this was true only for FVC. The initial FVC values were significantly lower in those with exposure longer than 10 years.

\section{Discussion}

Compared with a standard population (Jouasset, 1960) all the groups of cement workers showed lower values for $\mathrm{FEV}_{3 \cdot 0}, \mathrm{FVC}$, and the ratio between them. However the control (shipbuilding) workers also gave lower values suggesting that there is an ethnic difference in this respect between the population under investigation and that used as a standard. All workers showed a fall in FEV ${ }_{1.0}$ and FVC with time which was significant if the interval between examinations was over four years. The only significant difference between the cement workers and the controls was a higher value for $\mathrm{FEV}_{1.0} / \mathrm{FVC}(\%)$ in the control workers. This difference in the $\mathrm{FEV}_{1 \cdot 0} / \mathrm{FVC}$ ratio between the cement workers and the shipyard workers may be due to a lower initial value for FVC in the latter. 
In cement workers with chronic bronchitis and in cement workers who were smokers the decrement in ventilatory volumes was statistically more pronounced than in control workers in corresponding subgroups.

It is interesting, however, that in healthy cement and shipyard workers a significant reduction of forced expiratory volumes had occurred between the two examinations. As this was an unexpected result both subgroups of healthy workers were analysed according to other characteristics.

As the decrement of forced expiratory volumes was associated with the duration of interval between the first and repeated examination (Table 6) the same behaviour in the cement and control healthy workers may be explained partly by the difference in percentage of those re-examined after eight years.

In the interpretation of the findings presented in Table 3 it should also be borne in mind that in the group of healthy workers the initial values of ventilatory indices were significantly higher than in chronic bronchitics. This is particularly true for the control group. In the control group there was a noticeable drop of FVC values independent of the smoking habit.

The lack of stronger effects of chronic bronchitis on the degree of reduction in ventilatory volumes is in agreement with the findings of other authors (Fletcher, 1968; Howard, 1970; Brinkman, Block, and Cress, 1972; Bates, 1973). Neither is the effect of smoking very evident although this was more pronounced in cement workers than in controls. This phenomenon has also been observed in some other studies of industrial workers. Bouhuys, Schilling, and van de Woestijne (1969) found that in a study of active hemp workers 50 to 69 years old, moderate to heavy smokers had higher $\mathrm{FEV}_{1.0}$ than nonsmokers or light smokers. A self-selection process was thought to be the most likely cause of this phenomenon. On the basis of the fact that exsmokers had lower $\mathrm{FEV}_{\mathbf{1 \cdot 0}}$ than current, moderate, and heavy smokers these authors postulated that the selection could occur through the change of smoking habit of those smokers who react acutely after inhaling hemp dust (so called reactors). In interpreting the absence of an additive effect of cigarette smoke and asbestos dust on lung function Becklake et al. (1972) assumed that smoking might even have some protective effect against dust exposure. This assumption was based on a study of Sanchis, Polovich, and Chalmers (1971) who found that labelled aerosols do not reach the lung periphery in smokers to the same extent as they do in nonsmokers. Both of these explanations might be applicable to some extent to our results as well. The absence of a difference in the initial mean values of ventilatory indices between smokers and nonsmokers, particularly in cement workers, suggests that the self-selection process, if present, should have occurred before employment or within the first five years of work in a cement plant. The study included only those workers who had been employed for five years or longer.

In cement workers and controls the decrement of forced expiratory volumes is more pronounced in older than in younger workers. In interpreting the findings as regards age the cumulative effect of exposure (Table 7), which as a rule is longer the older the worker, and of smoking (for those who smoke) should also be taken into consideration.

It is interesting to analyse the change in the values of forced expiratory volumes in relation to the duration of interval between the first and repeated examination. Table 6 shows that there was a significant decrement of forced expiratory volumes both in cement workers and controls (with the exception of $\mathrm{FEV}_{1.0} / \mathrm{FVC}$ ) only if the examination was repeated after an interval of eight years. The results of examination after a four-year interval do not show a significant decrement in the volumes either in cement workers or in controls. However, the tendencies in the two groups differ: it is towards reduction in cement workers, but towards increase in controls except in the case of the mean FVC which is slightly lower.

\section{Conclusion}

This study of cement workers, with shipbuilding workers used as controls, has shown that in both groups there is a significant fall in ventilatory indices with time. This fall is greater than that which occurs in the standard population used for calculating the adjusted indices. The study suggests that the decrement in ventilatory indices is greater in cement workers than in controls but the difference is not statistically significant. This suggestion is based on the fact that considering relevant factors such as smoking, symptoms of chronic bronchitis, age, previous cement exposure, and re-examination interval the decline in ventilatory indices was faster in cement workers than in the control workers.

This study was supported by the US Department of Health, Education and Welfare, Public Health Service, National Institute of Occupational Safety and Health, Foreign Research Agreement No. 02-015-2.

\section{References}

Bates, D. V. (1973). The fate of the chronic bronchitis: A report of the ten-year follow-up in the Canadian Department of Veteran's Affairs Coordinated Study of Chronic Bronchitis. American Review of Respiratory Diseases, 108, 1043-1065.

Becklake, M. R., Fournier-Massey, G., Rossiter, C. E., 
and McDonald, J. C. (1972). Lung function in chrysotile asbestos mine and mill workers of Quebec. Archives of Environmertal Health, 24, 401-409.

Bouhuys, A., Schilling, R. S. F., and van de Woestijne, K. P. (1969). Cigarette smoking, occupational dust exposure and ventilatory capacity. Archives of Environmental Health, 19, 793-797.

Brinkman, G. L., Block, L. L., and Cress, C. (1972). Effects of bronchitis and occupation on pulmonary ventilation over an 11-year period. Journal of Occupational Medicine, 14, 615-620.

Fletcher, C. M. (1968). Prognosis in chronic bronchitis. Current research in chronic airways obstruction. In Proceedings of the Ninth Aspen Emphysema Conference: U.S. Department of Health, Education and Welfare, Public Health Service Publication 1717, pp. 309-315.
Howard, P. (1970). A long-term follow-up of respiratory symptoms and ventilatory function in a group of working men. British Journal of Industrial Medicine, 27, 326-333.

Jouasset, D. (1960). Normalisation des epreuves fonctionnelles respiratoires dans les pays de la communauté européene du charbon et de l'acier. Poumon et Coeur, 16, 1145-1159.

Kalačić, I. (1973). Ventilatory lung function in cement workers. Archives of Environmental Health, 26, 84-85.

Sanchis, J., Polovich, M., and Chalmers, R. (1971). Regional distribution and lung clearance mechanisms in smokers and non-smokers. Inhaled Particles and Vapours, Chap. III, pp. 183-191, Unwin Brothers, London.

Received for publication 1 July 1974.

Accepted for publication 23 July 1975.

\section{The November (1975) Issue}

Reading chest radiographs for pneumoconiosis by computer J. R. Jagoe and K. A. Paton

Classification of radiological appearance and the derivation of a numerical score A. J. Fox

Lung function in textile workers E. Žuškin, F. Valić, D. Butković, and A. Bouhuys

Comparative study of the smooth muscle contractor activity of airborne dusts and of dustiness in cotton, flax, and jute mills P. J. Nicholls and J. W. Skidmore

Epidemiological investigation of the role of family susceptibility and occupational and family histories in the development of byssinosis among workers exposed to flax dust $\mathrm{M}$. H. Noweir, E. K. Amine, and H. A. Osman

Occupational asthma after inhalation of dust of the proteolytic enzyme, papain J. Milne and S. Brand

Behaviour of rats exposed to trichloroethylene vapour A. P. Silverman and H. Williams

Effect of hydrofluoric acid on glucose metabolism of the mouse studied by whole-body autoradiography M. Watanabe, Y. Yoshida, M. Watanabe, M. Shimada, K. Kurimoto, and T. Kihara

Kinetic studies on sex difference in susceptibility to chronic benzene intoxication-with special reference to body fat content A. Sato, T. Nakajima, Y. Fujiwara, and N. Murayama

Tetramethyl lead absorption; a report of human exposure to a high level of tetramethyl lead J. Gething

Book reviews

Information section

Index

A number of copies are still available and may be obtained from the Publishing Manager, British Medical Association, Tavistock Square, London WC1H 9JR, price £2.50 (U.S.A. \$7.50). 